\title{
Assessment of Interaction Between A Waste Storage Dam And Instability In Downstream Right- Side Slope By 3D Numerical Analyses
}

Candan Gokceoğlu ( $\sim$ candan.gokceoglu@gmail.com )

Hacettepe Universitesi Muhendislik Fakultesi https://orcid.org/0000-0003-4762-9933

\section{Berna Unutmaz}

Hacettepe University: Hacettepe Universitesi

\section{Research Article}

Keywords: waste dam, slope stability, 3D numerical analysis, deformation, flysch zone

Posted Date: August 4th, 2021

DOl: https://doi.org/10.21203/rs.3.rs-724688/v1

License: (c) (1) This work is licensed under a Creative Commons Attribution 4.0 International License.

Read Full License

Version of Record: A version of this preprint was published at Environmental Earth Sciences on April 1st, 2022. See the published version at https://doi.org/10.1007/s12665-022-10361-5. 


\section{Abstract}

Waste dams (tailings) are used for storing the byproducts of mining operations and very common in mine industry. As the material they are storing can be harmful for the environment and the people in the vicinity, the construction of these dams is of high importance. During the construction phase, the topography of the site and geological- geotechnical parameters of the soils around the dam are as important as the stability and the leakage issues of the main dam body. In this paper, a nickel-ore waste dam located in Manisa-Gördes, Turkey is investigated in detail. At the downstream side of the dam, there was a slope instability at the right-hand side slopes due to improper loading on the top of these slopes. Whether this slope failure will affect the stability of main dam body or not is the main question of this study. Within these confines, 3D finite element analyses that cover a large area, including the dam, upstream and downstream sides and the waste have been performed before and after the planned downstream slope rehabilitation. The results show that after the rehabilitation of the slopes, the deformations decreased considerably and the waste dam became safer.

\section{Introduction}

A waste dam (tailings dam) is generally an earth-fill embankment dam used to store byproducts of mining operations after separating the ore from its gangue. Tailings stored in these dams can be liquid, solid, or a slurry of fine particles, and are usually highly toxic and potentially radioactive which are hazardous to environment. The main difference of these dams from any other earth-fill dam is, these are made permanently to store the waste from the ores. The leakage of these dams can be very dangerous for environment, people in the vicinity. The leakage is prevented by using geomembranes, clay cores and checked continuously. However, the construction steps of these dams are very similar to earth-fill dams that are built for other purposes such as hydropower, irrigation and etc.

As mentioned above, as the stored ore wastes can be very hazardous to environment, the stability of a mine waste dam (tailings dam) is considered to be very important in recent years, especially after failures of some of them. A chronological list of failures of mine waste dams can be seen in https://www.wiseuranium.org/mdaf.html (reached on March 30th, 2021). According to this list, the rate of tailings dam failures is increasing: about $65 \%$ of the total failures in the last 60 years occurred between 1990 to 2021. The failures are mainly due to heavy rain (Rico et al., 2008; Azam and Li, 2010), poor drainage conditions, poor detailing in the construction phases, overloading the dam with excessive amount of waste (higher than the designed level), static and seismic liquefaction (Ormann et al., 2013) and etc. The dam failures not only cause casualties but also the downstream side of the dam is covered with waste mud, which is toxic and environmentally hazardous. These failures are a big threat in the cities, forests, lakes and etc. in the vicinity of the dam (Rico et al., 2008).

Azam and Li (2010) has reviewed the tailing dam failures for the last 100 years. According to them, the most important cause of failure is unusual weather. Foundation failures were common in the past, but in recent years failures due to foundation have been reduced. Zandarin et al. (2009) has performed a 
detailed numerical analysis on a tailing dam from a nickel industry in Cuba and concluded that, the guidelines and codes in practice are valid and the pore pressures are very much important in stability of tailings, and must be operated carefully.

In addition to the causes of failures above, the topography of the site is also important in the stability of the dams. The slopes in the upstream and downstream sides of the dam can create various problems for the dam safety. However, most of the studies in literature (Ozcan et al., 2013; Cho and Song, 2014; Das and Hedge, 2020; Jin et al. 2020) deal with the stability of the dam body instead of the side slopes in the downstream and upstream. The main problem for the case in this study was the instability in the rightslope at the downstream side of the main dam body. A slope failure has occurred on the side slopes and there was a probability of this failure to affect the main dam body. For this reason, the purpose of this study is to assess the effects of instability in the downstream right - slopes of a tailing dam in the main dam body. The 3D numerical analyses were performed in that unstable area to understand if those instabilities affect the dam body or not. These 3D numerical analyses were performed using Midas GTX NX 3D. The whole area was covered in the analyses including the dam body, upstream and downstream sides so that the effects of the instabilities can be estimated accurately.

The deformations in the dam body are calculated as a result of these numerical analysis. According to the FEMA2005 (Federal Guidelines for Dam Safety Earthquake Analysis and Design of Dams), the expected performance of the dam is judged according to the severity of the deformation, such as loss of freeboard, potential of cracking leading to failure of the embankment or foundation. Similarly, the performance of the dam following a movement can be measured by considering the (i) the use of the reservoir; and (ii) the ability or lack thereof to quickly repair a damaged structure. It suggests a limiting deformation of $2 \mathrm{ft}(\sim 0.6 \mathrm{~m})$. Similarly, Cetin (2014) has summarized the allowable deformations of a dam body from various standards and says that 0 to $1.5 \mathrm{~m}$ permanent deformation is acceptable if the settlement of the dam is less than one tenth of the dam height according to Hawaiian Dam Safety Guide and Division of Safety of Dams (DSOD) California, however, according to FHWA-SA-97-076, the acceptable deformation is $0.3 \mathrm{~m}$.

According to U.S. Department of the Interior Bureau of Reclamation Design Standards No.13 Chap. 9 (Static Deformation Analyses), the magnitudes of horizontal deformations (into and down valley) are relatively small compared to the vertical settlement and this depends on the geometry, material and dam zone properties. For the dams that are built properly, the settlements at the crest after the construction are generally range between 0.2 and 0.4 percent and rarely exceed 0.5 percent of the embankment height. Keeping this in mind, the "1 percent rule" is used to make a conservative design. According to Chap. 13 (Seismic Analyses and Design), a predicted deformation of less than 1 foot $(\sim 0.3 \mathrm{~m})$ would not be a threat to the dam (unless a critical part of the dam is damaged). Similarly, it is also mentioned that, for any embankment dam, estimated deformations exceeding 3 feet would raise concern about cracking and loss of freeboard.

\section{General Characteristics Of The Study Area And Dam}


The site which is the subject of this paper is located $18 \mathrm{~km}$ from the city Manisa - Gördes of Turkey. It is located 789 to $980 \mathrm{~m}$ altitudes where the topography is steep and rugged due to landsliding. The location of the site is shown in Fig. 1.

\subsection{Geological and Geotechnical Characteristics of the Area}

The study area is located at the northwest part of Gordes Basin and in the Bornova Flysche Zone (Fig. 2). Several Tethyan suture belts are included by the eastern Mediterranean region around Turkey (Sengör and Yilmaz, 1981; Robertson, 2004). The Neotethyan Izmir-Ankara Suture Belt (IASB) is one of these suture belts within these ones (Sengör and Yilmaz, 1981). The IASB in northwestern Anatolia locates between the Sakarya Composite Terrane in the north (Göncüoglu et al., 1996) and the Tauride-Anatolide Platform in the south (Fig. 2, inset map; Tekin and Göncüoglu, 2007; Tekin et al., 2012). Stack of S-vergent nappes or tectonic slices of the intact or dismembered ophiolites, assemblages of the subduction-accretion prism with or without high pressure-low temperature metamorphism (ophiolitic mélanges), olistostromes of the fold-and thrust belt and finally the continental margin units of the Tauride-Anatolide Platform form the Izmir-Ankara Suture Belt (Goncuoglu et al., 1992; Okay et al., 1996; Goncuoglu, 2000; Goncuoglu et al., 2000; Tekin and Göncüoglu, 2007; Tekin et al., 2012). The Bornova Flysch Zone described by Okay and and Siyako (1993) is a part of the Izmir-Ankara Suture Belt including several imbricated tectonic units. Sandwiched between them are olistostromes that were formed in front of the ophiolitic nappes during their emplacement onto the Tauride-Anatolide Platform margin (Goncuoglu et al., 1996 and 2003; Tekin and Göncüoglu, 2007). Main litholologies forming the Bornova Flysche Zone are pillowed and massive volcanic rocks, radiolarian cherts and mudstones, pelagic limestones, blueschists, gabbros, serpentinites, recrystallized limestones (Tekin and Göncüoglu, 2007; Tekin et al., 2012). The age of the Bornova Flysche Zone is reported by Kaya (1972) and Konuk (1977) as Campanian to Danian. The waste water storage dam is located in the Bornova Flysch Zone (Fig. 2).

An extensive site investigation scheme has been performed at the area before beginning of construction. After some progress, when there was a slope instability problem at the right-side slope, additional site tests whose locations are shown in Fig. 3 were performed. According to these analyses, the generalized lithological profile and their parameters summarized in the following section have been developed.

Two detailed engineering geological and slope stability studies were performed by Tuncay et al. (2018) and Topal and Nalçakan (2019). Tuncay et al. (2018) performed 2D static and dynamic limit equilibrium analyzes for the dam body, and they found that there is not a slope stability problem for the dam body. Field observations were carried out by Topal and Nalçakan (2019), and then 7 geotechnical drillings, each $50 \mathrm{~m}$ deep, were performed in the landslide area, and inclinometers were installed in the completed boreholes. According to the data obtained from the drillings, mudstone, radiolarite, siltstone, sandstone, limestone and diabase belonging to the Bornova flysch zone were detected in the field. However, old waste material and clays were observed in the upper levels in the landslide zone. The mechanism of the landslide was described by Topal and Nalçakan (2019) (Fig. 4). The safe slope stability conditions were 
obtained as shown on Fig. 5. In the present study, the existing geometry of the landslide, and the safe slope geometry proposed by Topal and Nalçakan (2019) are considered for investigation of the effect of landslide and the excavation of the displaced material.

\subsection{Features of the Dam}

The crest height of the first stage is planned to be at $851 \mathrm{~m}$ from sea level and the height of the dam was about $60 \mathrm{~m}$ at this stage. The second stage is planned to be $14 \mathrm{~m}$ higher than the first one $(865 \mathrm{~m})$ in about 4 years' time and the last stage is to be at $886 \mathrm{~m}$ in about 9 years. In this study, the effects of slope instability on the existing dam (the second stage) are investigated. At the end on construction (final case, the third stage) the dam height reaches up to $100 \mathrm{~m}$. There were no problems after the construction of the first stage. However, after construction of the second stage there was a slope stability problem at the downstream right - side slope (Fig. 3) which is due to over loading of the excavated material on the slope.

The waste dam is a fill dam which consists of rock- and earth-fills. The upstream part of the dam is filled with earth-fill material (1B) whereas the downstream part is rock-fill (1C) for the first stage (Table 1). The sand filters are used in the dam body and drains the water till the drainage material beneath the dam body. The upstream surface of the dam is covered with geomembranes so that the waste cannot leak through the dam body. These geomembranes are GCL (geosynthetic clay liners), and HDPE and they are placed over a clay surface so that the leakage will be avoided, and the waste will settle faster. The minimum factor of safety is selected as $1.3,1.5$ and 1.0 for static empty reservoir, static case when the reservoir is full and seismic cases respectively.

The safe upstream slope is designed to be $1 \mathrm{~V}: 2.9 \mathrm{H}$ for the earth-fill part (i.e. for the first $35 \mathrm{~m}$ part from the bottom). At every $10 \mathrm{~m}$, there is a berm of $5 \mathrm{~m}$. For the upper parts of the upstream where there is rock-fill, the slope is $1 \mathrm{~V}: 2 \mathrm{H}$. For the downstream part, a slope of $1 \mathrm{~V}: 2.5 \mathrm{H}$ is found to be safe with a larger $(6 \mathrm{~m})$ berm at every $20 \mathrm{~m}$. A typical cross-section of the dam, including the materials used can be seen in Fig. 6 at this stage. 
Table 1

Properties of the dam material

\begin{tabular}{|lllll|}
\hline Zone & $\begin{array}{l}\text { Unit } \\
\text { Weight, } \mathbf{Y} \\
\left(\mathbf{k N} / \mathbf{m}^{3}\right)\end{array}$ & $\begin{array}{l}\text { Internal Friction } \\
\text { Angle, } \boldsymbol{\varphi}\end{array}$ & $\begin{array}{l}\text { Cohesion, } \\
\mathbf{C}\end{array}$ & $\begin{array}{l}\text { Modulus of Elasticity } \\
\mathbf{( k P a )}\end{array}$ \\
\hline 1A - Compacted Clay & 17 & 25 & - & \\
\hline 1B - Selected Earth Fill & 18 & 26 & 20 & $1 \times 10^{5}$ \\
\hline 1C - Selected Rock Fill & 18 & 32 & - & $2 \times 10^{5}$ \\
\hline 2A - Sand Filter & 19 & 34 & - & $1.5 \times 10^{5}$ \\
\hline 2B - Filter/Drainage & 19 & 34 & - & - \\
\hline Colluvium & 18 & 26 & 20 & - \\
\hline $\begin{array}{l}\text { Colluvium shear zone } \\
\text { foundation }\end{array}$ & 18 & 18.5 & 0 & - \\
\hline Waste & 23 & 20 & 0 & - \\
\hline
\end{tabular}

\section{Numerical Analyses}

3-dimesional (3D) numerical analyses are extremely useful tools to predict the deformations and to consider interaction two or more event and/or structures (Gokceoglu et al., 2016 and 2021; Komu et al., 2020; Aygar and Gokceoglu, 2021). For this reason, in the present study, to understand the effects of the landslide and the excavations to obtain safe slope geometry, the 3D numerical analyses are performed. Midas GTS NX 3D software has been used in the analyses. The analyses were performed to assess the effects of the instability at the slope in resting between the dam body and the unstable portion on the dam body. The analyses consist of: (i) current state, and (ii) the safe slope geometry (after removing the sliding mass, making a $2 \mathrm{H} / 1 \mathrm{~V}$ slope at the rock slopes). The generalized soil and rock parameters used in the numerical analyses are presented in Tables 2 and 3 . These parameters were obtained from the detailed site investigation performed at the site before and during the construction process. Additionally, RocLab software was also used to determine the parameters related with rock mass. An example case is shown in Fig. 7 for siltstone-mudstone alternation. 
Table 2

Generalized geotechnical parameters used in the analyses

\begin{tabular}{|c|c|c|c|c|}
\hline Geological unit & $\begin{array}{l}\text { Unit weight } \\
\left(\mathrm{kN} / \mathrm{m}^{3}\right)\end{array}$ & $\begin{array}{l}\text { Cohesion } \\
(\mathrm{kPa})\end{array}$ & $\begin{array}{l}\text { Internal Friction } \\
\text { Angle }\left({ }^{(}\right)\end{array}$ & $\begin{array}{l}\text { Modulus of } \\
\text { Elasticity (MPa) }\end{array}$ \\
\hline Clayey-Sandy Fill & $19 / 20$ & 1 & 35 & 20.00 \\
\hline $\begin{array}{l}\text { Siltstone - Mudstone } \\
\text { alternation }\end{array}$ & $24 / 25$ & & & 197.10 \\
\hline Siltstone & $27 / 28$ & & & 364.46 \\
\hline Mudstone & $27 / 28$ & & & 210.82 \\
\hline Slope wash & $19 / 20$ & 5 & 35 & 50.00 \\
\hline Diabase & $25 / 26$ & & & 1360.88 \\
\hline Serpentine & $23 / 24$ & & & 205.52 \\
\hline Limestone & $25.7 / 26$ & & & 996.29 \\
\hline Waste & 23 & & & \\
\hline Rockfill & $18 / 19$ & 0 & 32 & 200.00 \\
\hline Selected Soil Fill & $18 / 19$ & 20 & 26 & 100.00 \\
\hline
\end{tabular}

Table 3

Generalized intact rock and rock mass parameters used in the analyses

\begin{tabular}{|lllll|}
\hline Geological unit & $\begin{array}{l}\text { Uniaxial Compressive Strength } \\
\text { UCS (MPa) }\end{array}$ & GSI & $\mathbf{m}_{\mathbf{i}}$ & Poisson's Ratio \\
\hline Siltstone - Mudstone alternation & 21.04 & 17 & 6 & 0.27 \\
\hline Siltstone & 22.80 & 20 & 7 & 0.25 \\
\hline Mudstone & 19.28 & 15 & 4 & 0.29 \\
\hline Diabase & 40.00 & 35 & 10 & 0.19 \\
\hline Serpentine & 15.00 & 20 & 4 & 0.23 \\
\hline Limestone & 23.50 & 34 & 9 & 0.28 \\
\hline
\end{tabular}

\subsection{Current State}

The 3D model of the current state of the area is analyzed by using Midas GTS NX software as stated above. Figure 8 presents the generated model. In this model, the light green part is the down-stream side of the dam. The unstable slope zone is shown with a circle, the bright green part especially. The different colors in this model is actually not different soil types but they were used for constructing the geometry of the model. The static boundary conditions were used in the model, i.e. fixed in all directions at the 
bottom. The sides can move freely in z-direction but fixed in $\mathrm{x}$ - and $\mathrm{y}$ - directions. In these analyses, the parameters presented in Tables 2 and 3 have been used in the corresponding zones and the maximum waste level, which is $+863 \mathrm{~m}$, is modeled to be on the safe side.

After performing the analyses, the obtained deformations in x-direction is presented in Fig. 9a. The maximum deformation is calculated about $54 \mathrm{~cm}$ in -x-direction in the whole area. This is the point, where the slope instability occurred. However, in the mean dam body the maximum deformation in $\mathrm{x}$-direction is calculated to be about $9.3 \mathrm{~cm}$ at the left-hand side. Although this $9.3 \mathrm{~cm}$ is acceptable in design, the important aspect in this analysis is the $54 \mathrm{~cm}$ displacement in the downstream side slopes. Those slopes should be remediated so that no slope failure occurs in that area. Similarly, the deformations in ydirection are presented in Fig. 9b. As can be seen from this figure, the maximum deformations in this direction are calculated in between 3 to $5.75 \mathrm{~cm}$. Deformations in z-direction, i.e. settlements, are presented in Fig. 9c. The maximum deformations are expected in z-direction and as expected a value of $34 \mathrm{~cm}$ is calculated in this direction.

\subsection{Removing the sliding mass with $2 \mathrm{H} / 1 \mathrm{~V}$ slope at the rock slopes (Safe Slope Geometry)}

For removing the sliding mass at the downstream side, a slope was designed with $2 \mathrm{H} / 1 \mathrm{~V}$ slopes at the rock slopes as shown in Fig. 6 . The area is now modeled with this geometry, using the similar soil and rock properties (Fig. 10). Similar to the above, the waste was modeled to be at its maximum height for the operational stage. The yellow circle shows the location of the slopes proposed. These slopes may seem very close to the boundary. However, the appropriate boundary conditions were selected and the effect of these boundaries in the results is tried to minimized. Also, as the effects of these slopes on the dam body is the main point of investigation of this study, it is thought that these boundaries will not have an impact at those points.

After the cut in the unstable slopes, the maximum deformations observed in $\mathrm{x}$-direction reduces to about $17 \mathrm{~cm}$ which is shown in Fig. 11a. The deformations at the dam body is negligible after cutting these slopes. Similarly, when observing the deformations in y-direction, it can be seen that the maximum deformation is about $9 \mathrm{~cm}$ in the slopes and $4.2 \mathrm{~cm}$ in the dam body which is shown in Fig. 11b. Figure $12 \mathrm{c}$ shows the settlements after excavation of the slopes. As can be expected there is not much difference between the settlement values with the previous case, as the settlement of the dam body is mainly due to its weight.

To summarize the findings of the numerical analyses, the deformation values are presented in Tables 4 and 5 for the side slopes and the dam body, respectively. According to these tables, it can be seen that after the construction of the side slopes, the deformation reduces. 
Table 4

Calculated deformation values at the downstream side slopes

\begin{tabular}{|lll|}
\hline Stage & $\begin{array}{l}\text { Deformation in x- } \\
\text { direction } \\
(\mathbf{c m})\end{array}$ & $\begin{array}{l}\text { Deformation in } \mathbf{y}- \\
\text { direction } \\
\text { (cm) }\end{array}$ \\
\hline $\begin{array}{l}\text { Current stage, static } \\
\text { (2nd phase) }\end{array}$ & 54.45 & 21.70 \\
\hline $\begin{array}{l}\text { Current stage with side slopes at downstream, static } \\
\text { (2nd phase) }\end{array}$ & 16.97 & 9.15 \\
\hline
\end{tabular}

Table 5

Calculated deformation values at the dam body

\begin{tabular}{|llll|}
\hline Stage & $\begin{array}{l}\text { Deformation in } \\
\text { x-direction } \\
(\mathbf{c m})\end{array}$ & $\begin{array}{l}\text { Deformation in } \\
\text { y-direction } \\
(\mathbf{c m})\end{array}$ & $\begin{array}{l}\text { Deformation in } \\
\text { z-direction } \\
\text { (cm) }\end{array}$ \\
\hline $\begin{array}{l}\text { Current stage, static } \\
\text { (2nd phase) }\end{array}$ & 9.29 & 5.75 & 34.04 \\
\hline $\begin{array}{l}\text { Current stage with side slopes at } \\
\text { downstream, static (2nd phase) }\end{array}$ & $\sim 1.50$ & 4.16 & 37.66 \\
\hline
\end{tabular}

According to "Fill Dams Design Standards" a settlement of about 2-4\%o of the total dam height is acceptable. This allows a settlement of 20 to $40 \mathrm{~cm}$ for a dam of $100 \mathrm{~m}$, which is the case in this study.

\section{Conclusions}

In this study, 3D numerical analyses of a waste dam have been performed, covering all the surrounding area. The aim was to see the effects of the unstable downstream side slopes on the dam body. The downstream right - side slopes became unstable after some of the excavated material has been loaded on that area. Although no problem was foreseen for the second stage of the dam, that unstable slope may have created a problem for the last stage as the toe of the downstream side of the dam reaches till the toe of the unstable part. For this reason, the stability of the right-side slopes should be provided before the construction of the last stage.

For the analyses, the engineering parameters were obtained from the detailed site survey performed before and during the construction. As the safety of the dam is extremely important, extensive site investigations were performed. The analyses were performed in two stages such as current state and current state with safe slope geometry.

In the analyses of the current state, the deformations reached up to $55 \mathrm{~cm}$ in the sliding area. Hence, a slope design (with $2 \mathrm{H} / 1 \mathrm{~V}$ slope) is proposed and the slope side which reduced these deformations to about $17 \mathrm{~cm}$ which is acceptable. 
The excavation of the proposed side slopes, there may be a water flow through the rock discontinuities as the groundwater level is near the ground surface. Therefore, it is strongly recommended to take the measures to drain water for the long-term stability. Similarly, water resting in the impermeable rocks can create additional water pressure on the slopes which may result in slope failures. Hence, the drainage of the water must be assured including both the surface and ground waters.

In cases where two structures that affect each other or a failure are likely to affect another structure, 3dimensional analyzes must be performed. The results of this study, which is carried out as an example of such a situation, express both the current state of a slope instability that may affect a dam, and the deformations that will occur in case of excavation of the displaced material. Consequently, it is recommended to use the methodology presented in this study to understand the safety of the waste dams, which are extremely critical structures, to determine the deformations that will occur beforehand and to take the necessary engineering measures.

\section{Declarations}

As the authors, we declare that we have no conflict of interest with any person or institution.

\section{Acknowledgement}

The authors thank to Meta - Nikel A.S. for permission of data used in the study. In addition, the authors also want to thank to Mr. Yasin Baskose for his support during the analysis phase.

\section{References}

1. Aygar, E.B., Gokceoglu, C., 2021. Analytical solutions and 3D numerical analyses of a shallow tunnel excavated in weak ground: a case from Turkey. International Journal of Geo-Engineering, 12, 9 , https://doi.org/10.1186/s40703-021-00142-7

2. Azam S, Li Q. Tailings dam failures: a review of the last one hundred years. Geotechnical News Magazine, December 2010.

3. Çetin, K., Ö., 2014, Dolgu Barajlar İçin Sismik Tasarım Ve Performans Kriterleri (Seısmıc Desıgn And Performance Crıterıa For Earthfıll And Rockfıll Dams); Zemin Mekaniği ve Temel Mühendisliği Onbeşinci Ulusal Kongresi, Orta Doğu Teknik Üniversitesi, Ankara (in Turkish)

4. Cho, YC, Song YS (2014). "Deformation measurements and a stability analysis of the slope at acoal mine waste dump", Ecological Engineering 68 (2014) 189-199.

5. Das T., Hegde A. (2020) A Comparative Deterministic and Probabilistic Stability Analysis of Rock-Fill Tailing Dam. In: Prashant A., Sachan A., Desai C. (eds) Advances in Computer Methods and Geomechanics. Lecture Notes in Civil Engineering, vol 55. Springer, Singapore. https://doi.org/10.1007/978-981-15-0886-8_49

6. FEMA 2005, Federal Guidelines for Dam Safety, Earthquake Analyses and Design of Dams, May 2005 
7. Gokceoglu, C., Turer, A., Nefeslioglu, H.A., Turer, D., Meral, C., 2016. Safety assessment of limestonebased engineering structures to be partially flooded by dam water: A case study from northeastern Turkey. Engineering Geology, 209, 44-55, https://doi.org/10.1016/j.enggeo.2016.05.003

8. Gokceoglu, C., Kocaman, S., Nefeslioglu, H.A., Ok, A.O., 2021. Use of multisensor and multitemporal geospatial datasets to extract the foundation characteristics of a large building: a case study. Bulletin of Engineering Geology and the Environment, 80 (4=, 3251-3269, DOI: 10.1007/s10064-02102116-6

9. Goncuoglu M. C., 2000. Restoration of an alpine foreland-thrust belt: Kutahya - Bolkardag zone of the Tauride-Anatolide platform, NW Turkey. Geology 2000, Vienna, April 14-17, 2000, Terra Nostra, Schriften der Alfred Wegener Stiftung, 2000/1: 47.

10. Goncuoglu M. C., Dirik K., Kozlu H., 1996. Pre-alpine and alpine terranes in Turkey: explanatory notes to the terrane map of Turkey. An. Géol. des Pays Hél., 37: 515-536.

11. Goncuoglu M. C., Turhan N., Tekin U. K., 2003. Evidence for the Triassic rifting and opening of the Neotethyan Izmir-Ankara Ocean, northern edge of the Tauride-Anatolide platform, Turkey. Boll. della Soc. Geol. It., Spec. Vol., 2: 203-212.

12. Goncuoglu M. C., Ozcan A., Turhan N., Isik A., 1992. Stratigraphy of the Kutahya region. A Geotraverse Across Suture Zones in NW Anatolia, Guide Book. Gen. Direc. of Min. Res. and Exp. Publ.: 3-8.

13. Goncuoglu M. C., Turhan N., Senturk K., Ozcan A., Uysal S., 2000. A geotraverse across NW Turkey: tectonic units of the Central Sakarya region and their tectonic evolution. In: E. Bozkurt et al. (Eds.), Tectonics and Magmatism in Turkey and the Surrounding Area. Geol. Soc. of London, Spec. Publ. 173: 139-161.

14. Jin, J., Ding, Q., Cui, H. et al. Dynamic response characteristics of a tailing dam determined by shaking table tests. Arab J Geosci 13, 897 (2020). https://doi.org/10.1007/s12517-020-05878-7.

15. Kaya O., 1972. Tavşanlı yöresi ofiyolit sorununun ana çizgileri. (Main issues of the ophiolite problem in Tavsanli area). Bull. of the Geol. Soc. of Turkey, 15: 26-108 (in Turkish with English abstract).

16. Komu, M.P., Guney, U., Kilickaya, T.E., Gokceoglu, C., 2020. Using 3D Numerical Analysis for the Assessment of Tunnel-Landslide Relationship: Bahce-Nurdag Tunnel (South of Turkey). Geotech Geol Eng, 38, 1237-1254, https://doi.org/10.1007/s10706-019-01084-9

17. Konuk T.,1977. Bornova Filişinin yaşı hakkında (On the age of the Bornova Flysch Zone). Ege Univer., Bull. of the Fac. of Sci. B1: 65-74 (in Turkish).

18. Okay A. I., Siyako M., 1993. The new position of the Izmir-Ankara Neo-tethyan suture between Izmir and Balıkesir. Proc. of Ozan Sungurlu Symp., Tectonics and Hydrocarbon Potential of Anatolia and Surrounding Regions: 333-354.

19. Okay A. I., Satir M., Maluski H., Siyako M., Metzger R., Akyuz S., 1996. Paleo and Neo-Tethyan events in northwest Turkey: geologic and geochronological constraints. In: A. Yin and T. M. Harrison (Eds.), Tectonic Evolution of Asia, Cambridge Univ. Press: 420-441. 
20. Ozcan, N.T., Ulusay, R., Isik, N.S., 2013. A study on geotechnical characterization and stability of downstream slope of a tailings dam to improve its storage capacity (Turkey). Environ Earth Sci 69, 1871-1890 (2013). https://doi.org/10.1007/s12665-012-2016-1

21. Robertson A. H. F., 2004. Development of concepts concerning the genesis and emplacement of Tethyan ophiolites in the eastern Mediterranean and Oman regions. Earth-Science Rev., 66: 331-387.

22. Rico, M, Benito, G., Salgueiro AR, Díez-Herrero A., Pereira HG. (2008). "Reported tailings dam failures: A review of the European incidents in the worldwide context", Journal of Hazardous Materials, 152(2), 846-852.

23. Rocscience, I. (2007). RocLab Version 1.031-Rock mass strength analysis using the Hoek-Brown failure criterion.

24. Sengor A. M. C., Yilmaz Y., 1981. Tethyan evolution of Turkey: a plate tectonic approach. Tectonophysics, 75: 181-241.

25. Tekin, U. K., Göncüoğlu, M. C., 2007. Discovery of oldest (late Ladinian to middle Carnian) radiolarian assemblages from the Bornova Flysch Zone in western Turkey: Implications for the evolution of the Neotethyan Izmir-Ankara Ocean. Ofioliti 32, 2, 131-150.

26. Tekin, U. K., Göncüoğlu, M. C., Uzuncimen, S., 2012. Radiolarian assemblages from an olistolith with Middle - Late Jurassic to early Late Cretaceous pelagic deposition within the Bornova Flysch Zone in western Turkey. Bulletin de la Société Géologique de France 183, 4, 307-318.

27. Topal T., Nalçakan, M. S., 2019. Manisa Gördes Meta Atık Depolama Barajı Adt Mansabında Meydana Gelen Duraysızlıkların 3.Kademe Gövde İnşası Öncesinde Sahadaki Etkilerinin İncelenmesi Ve Alınması Gereken Önlemlerle İlgili Jeolojik ve Geoteknik Rapor, Kilci Mühendislik Müşavirlik Proje Ltd. Şti., 164s.

28. Tuncay, E., Unutmaz, B., Hindistan, M.A., Ünver, B., 2018. Gördes Nikel-Kobalt İşletmesi Atık Depolama Tesisi (ADT) Mansap Tarafı Sağ Yamacında Gelişen Duraysızlıkların ADT Baraj Gövdesine Etkisinin Araştırılması (Final Rapor), H. Ü. Döner Sermaye İşletme Müdürlüğü, Proje No: M.JO.P75, 58s.

29. Zandarin MT, Oldecop LA, Rodriguez R, Zabala F, 2009. The role of capillary water in the stability of tailing dams. Engineering Geology, 105 (1-2) 108-118

\section{Figures}



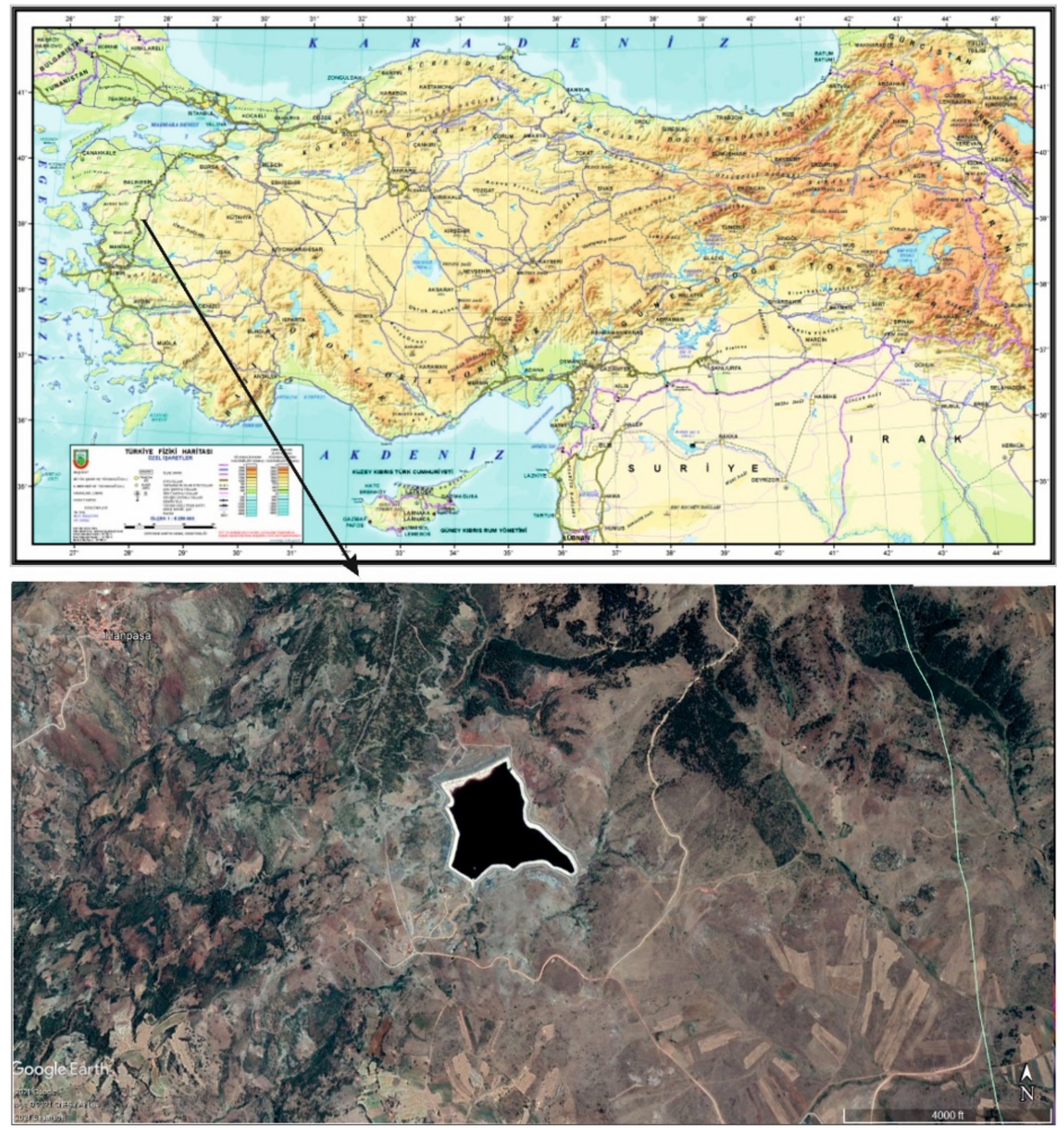

Figure 1

Location of the site 


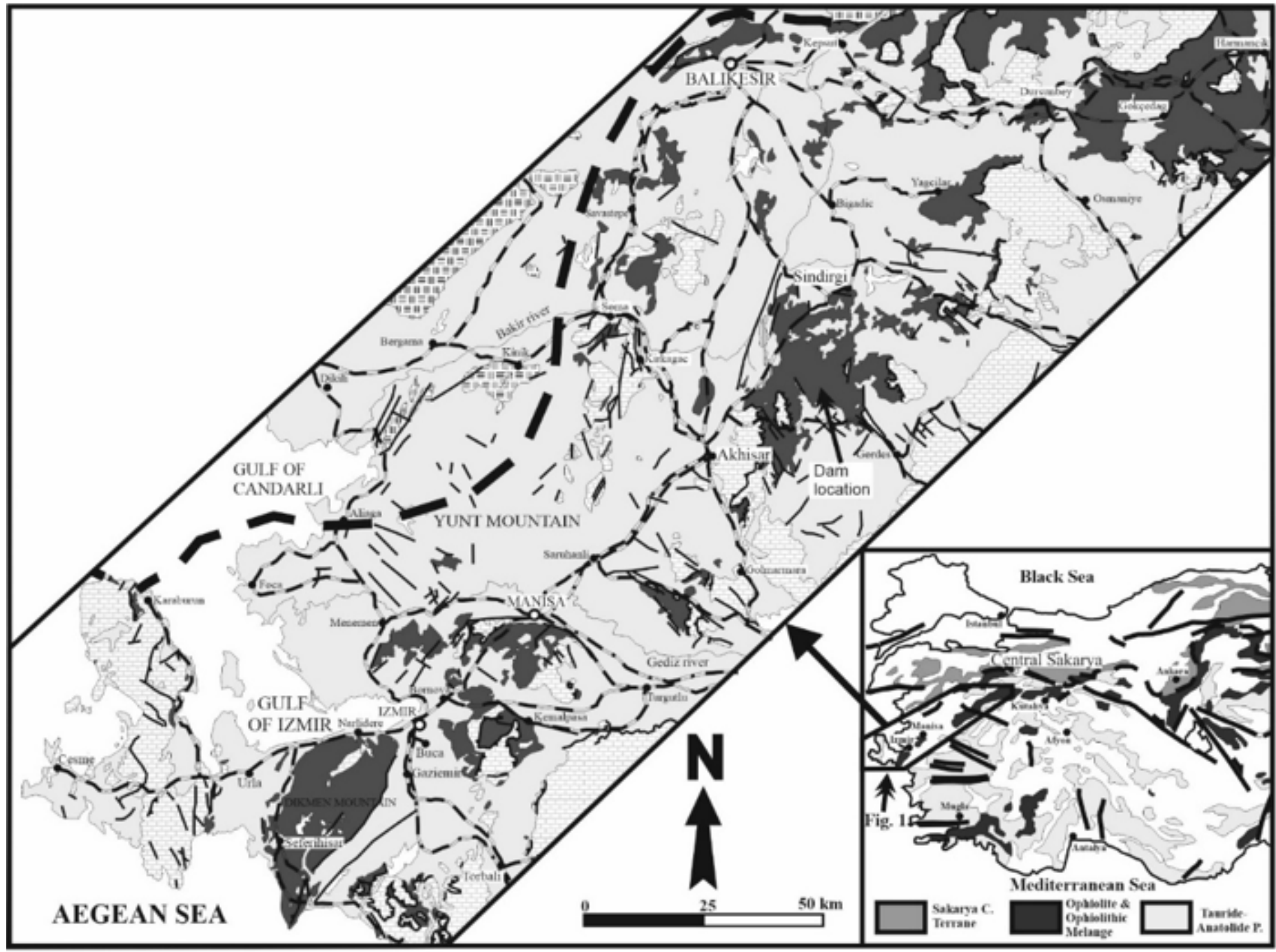

$\square_{\text {Fault }}$

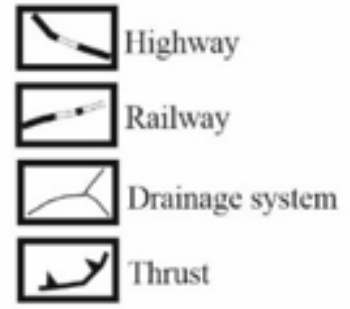

Post-Eocene rock units

Eocene carbonate and clastic sequences

Ophiolite and ophiolitic melange complexes of

the Izmur-Ankara Suture Belt

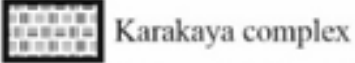

Paleozoic-Mesozoic carbonate sequences of

the Tauride-Anatolide Platform

Figure 2

Simplified geological map of the Bornova Flysch Zone (after Tekin and Göncüoğlu, 2007) (The inset map published by Göncüoğlu et al. (1996) portrays the distribution of Alpine terrannes) 


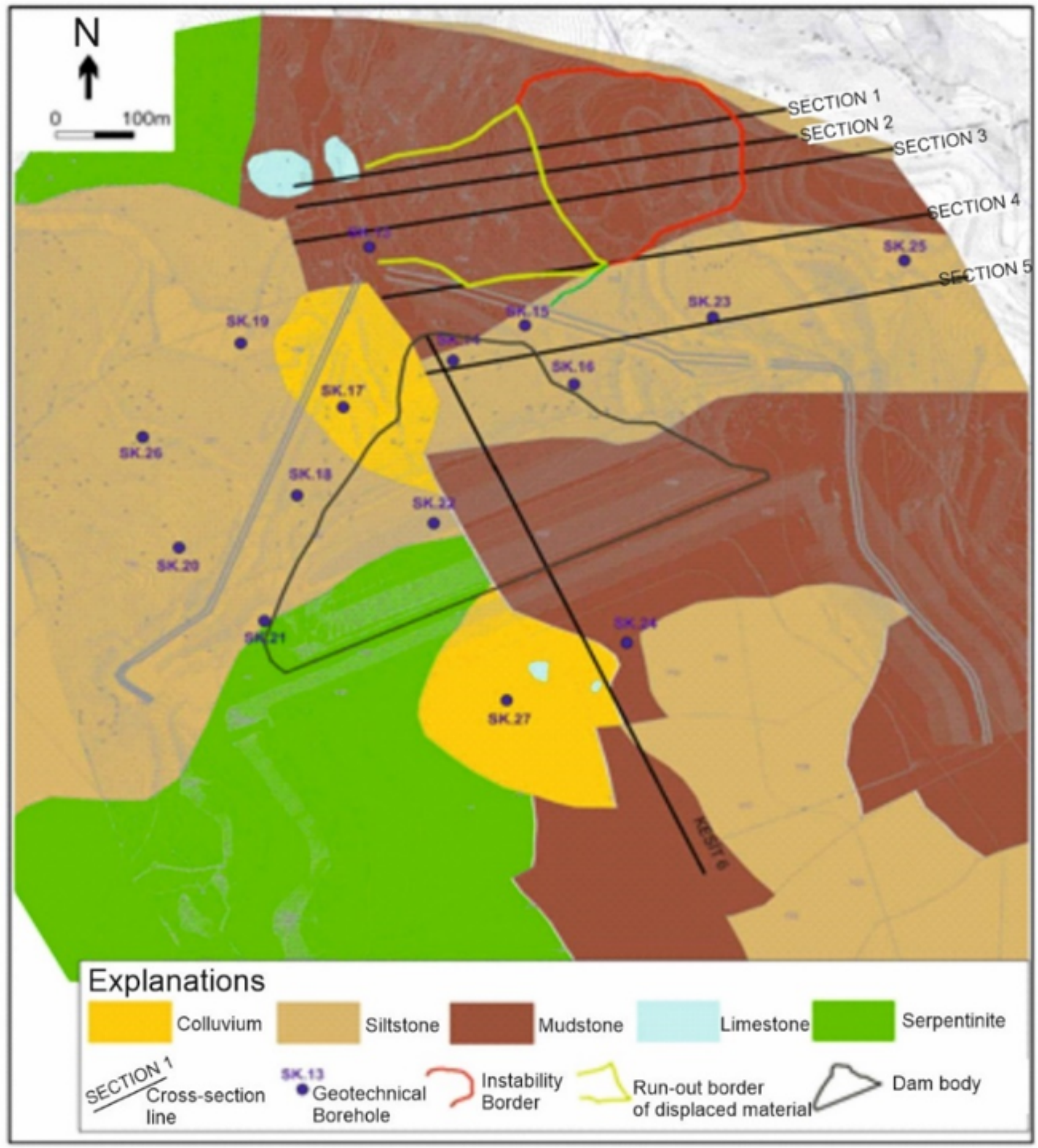

\section{Figure 3}

The slope instability borders and borehole locations (after Topal and Nalçakan, 2019) 


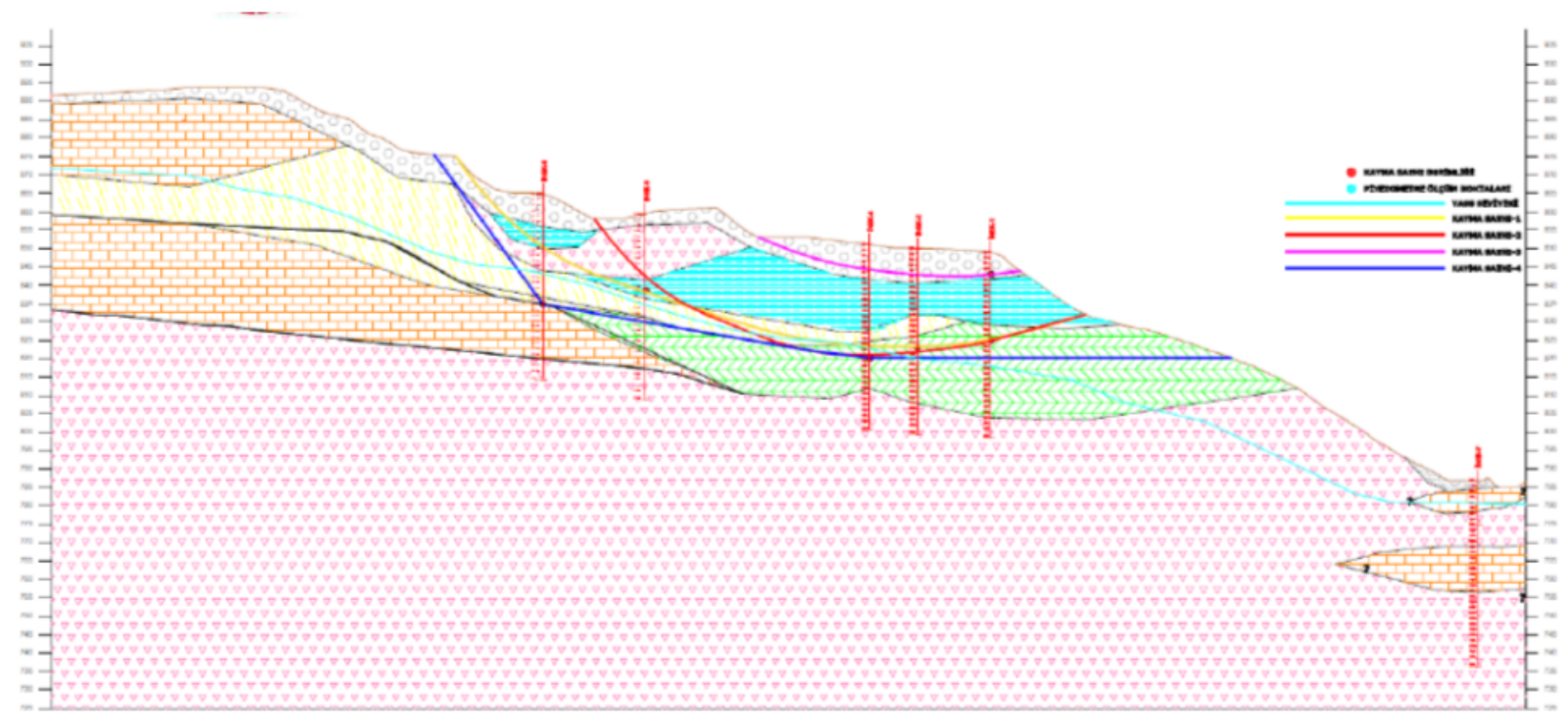

Figure 4

The mechanism of the landslide occurred at the right-downstream slope of the dam (Section 2 in Figure 3) (Topal and Nalçakan, 2019).

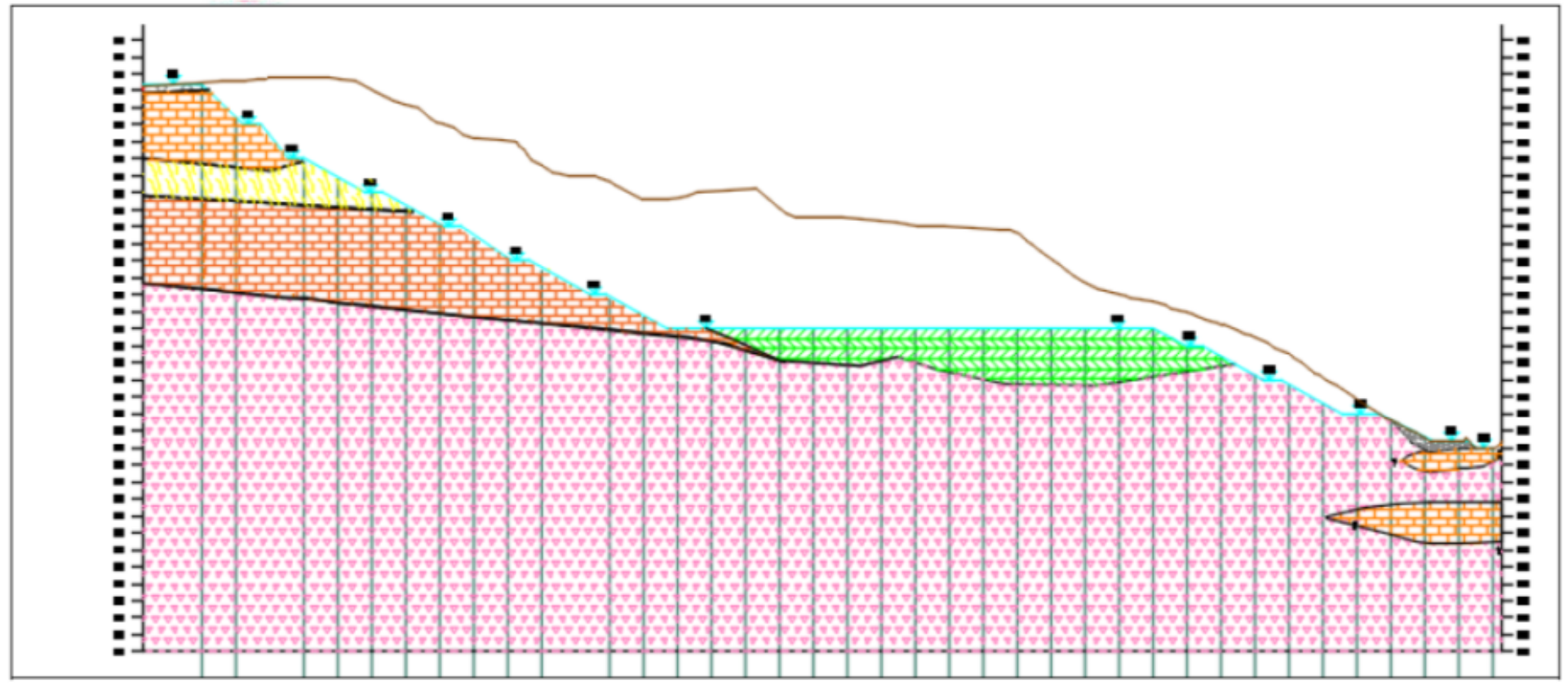

Figure 5

The safe slope geometry proposed by Topal and Nalçakan (2019) (Section 3 in Figure 3) 


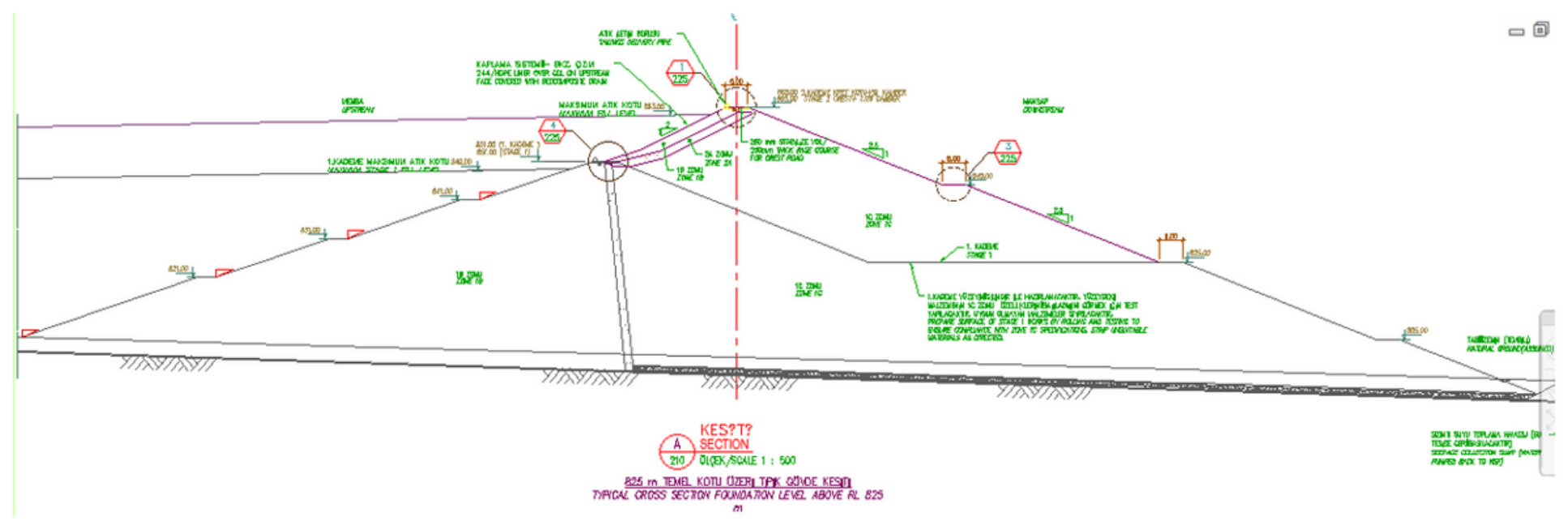

Figure 6

A typical cross-section of the dam

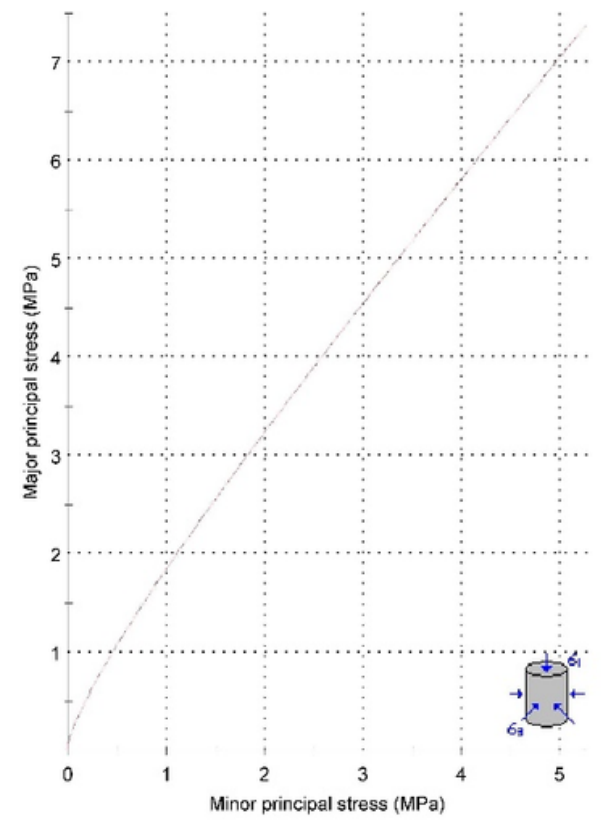

Analysis of Rock Strength using RocLab

Hoek-Brown Classification

intact uniaxial comp. strength (sigci) $=21.04 \mathrm{MPa}$ $\mathrm{GSI}=17 \mathrm{mi}=6 \quad$ Disturbance factor $(\mathrm{D})=0.7$ intact modulus (El) $=7890 \mathrm{MPa}$

modulus ratio (MR) $=375$

Hoek-Brown Criterion

$\mathrm{mb}=0.063 \quad \mathrm{~s}=5.97 \mathrm{e}-6 \quad \mathrm{a}=0.553$

Mohr-Coulomb Fit

$k$ Mass Parameters

tensile strength $=-0.002 \mathrm{MPa}$
trents

tensile strength $=-0.002 \mathrm{MPa}$
uniaxial compressive strength $=0.027 \mathrm{MPa}$

global strength $=0.476 \mathrm{MPa}$

deformation modulus $=197.10 \mathrm{MPa}$

Figure 7 
The non-linear failure envelope obtained from RocLab for siltstone-mudstone alternation (Rock Science, 2007).

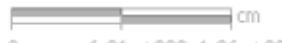

$6.81 \mathrm{e}+0031,36 \mathrm{e}+004$

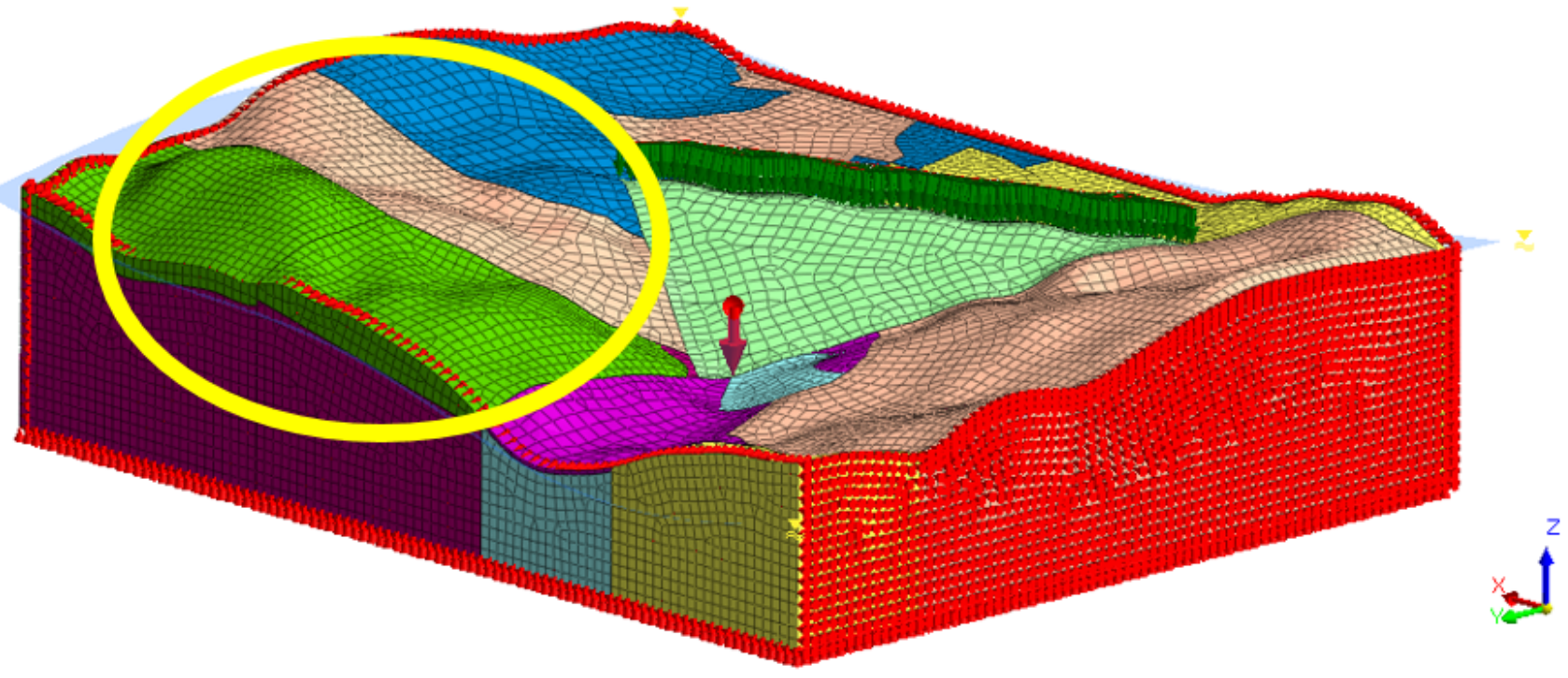

Figure 8

3D model of the site (The circle contains unstable slopes) 
(a)

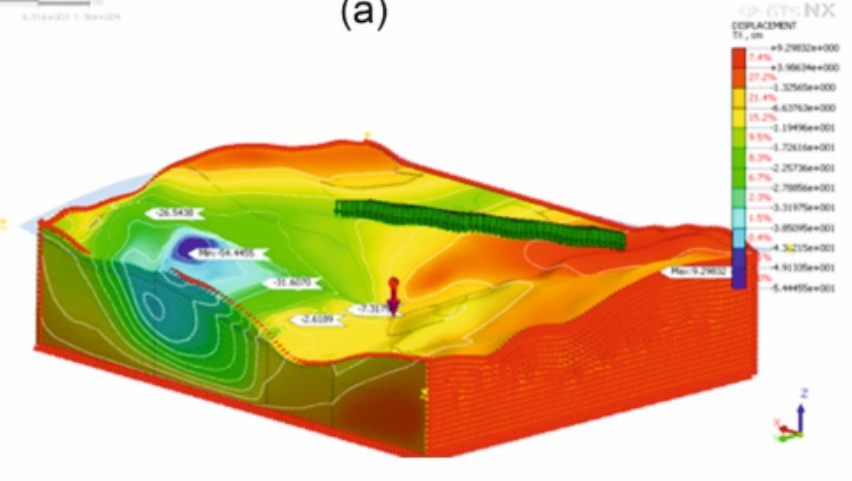

(b)

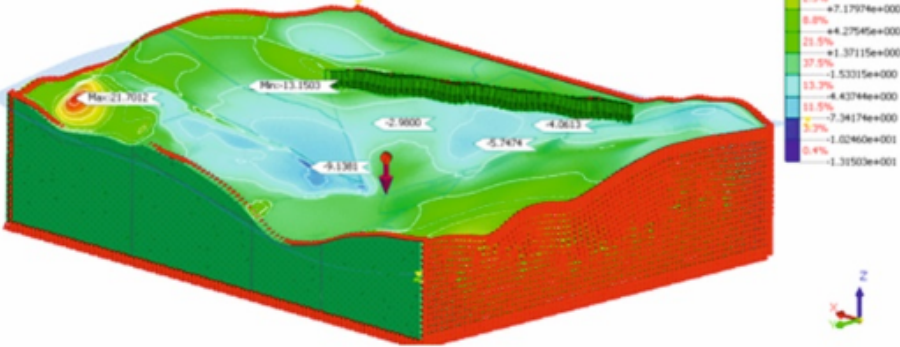

(c)

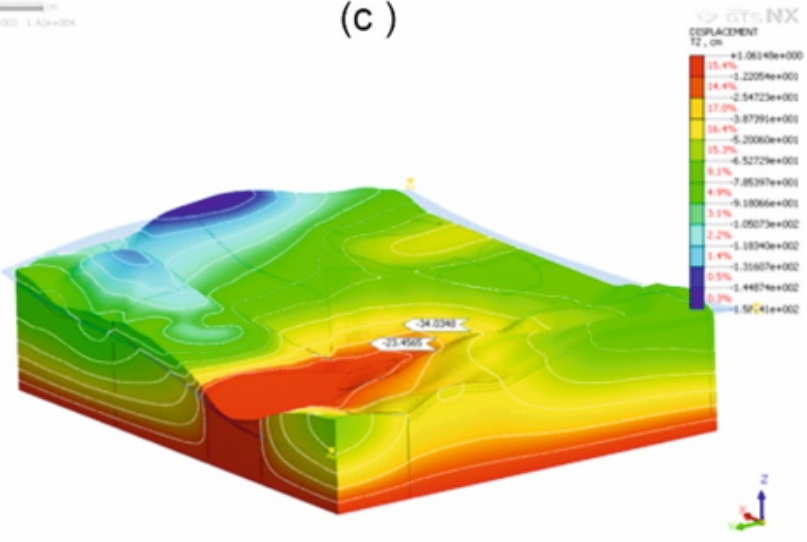

Figure 9

Deformations in (a) x-direction, (b) y-direction, and (c) z-direction at the current state 

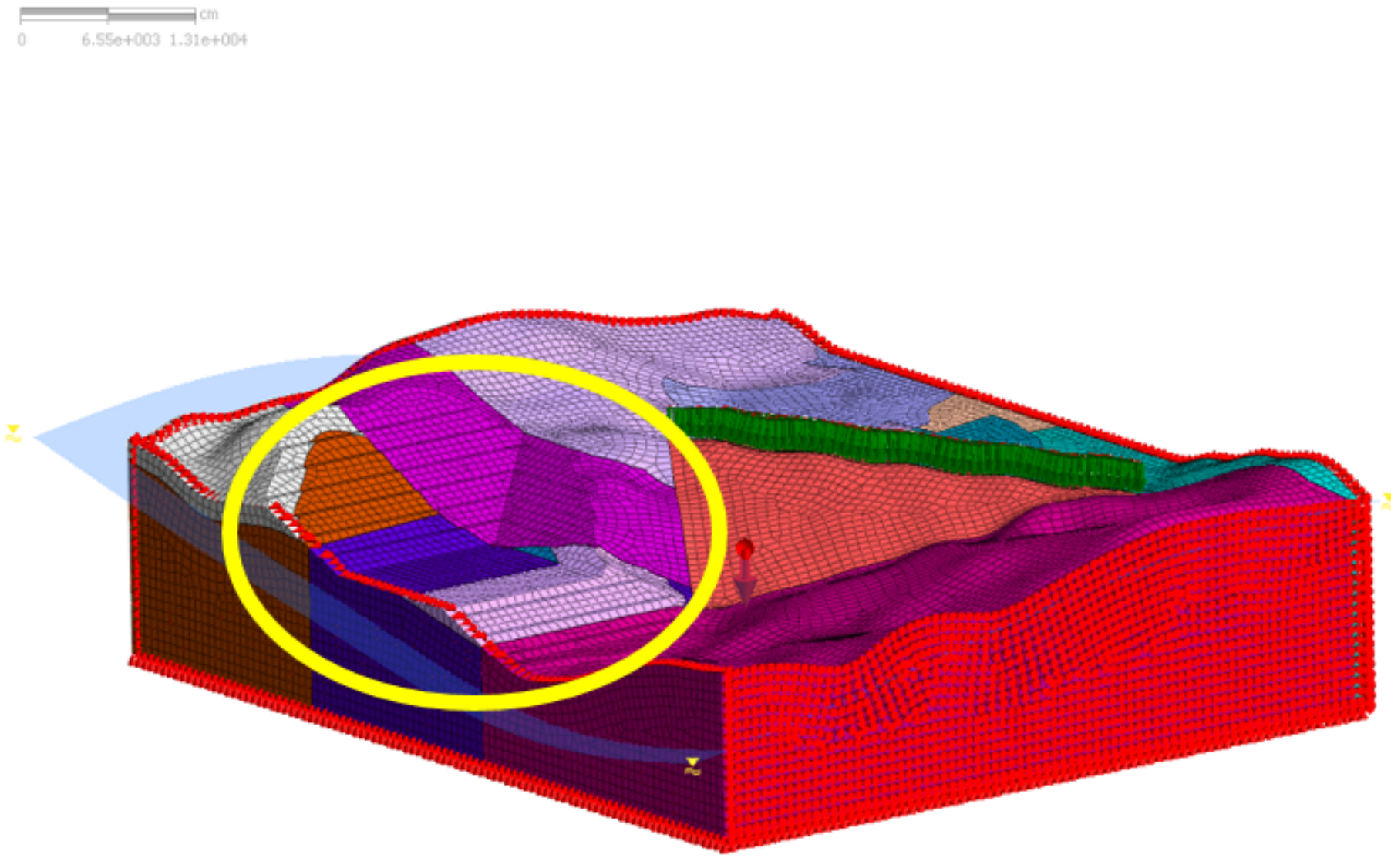

Figure 10

$3 \mathrm{D}$ model of the site with the proposed rock slopes $(2 \mathrm{H} / 1 \mathrm{~V})$ 

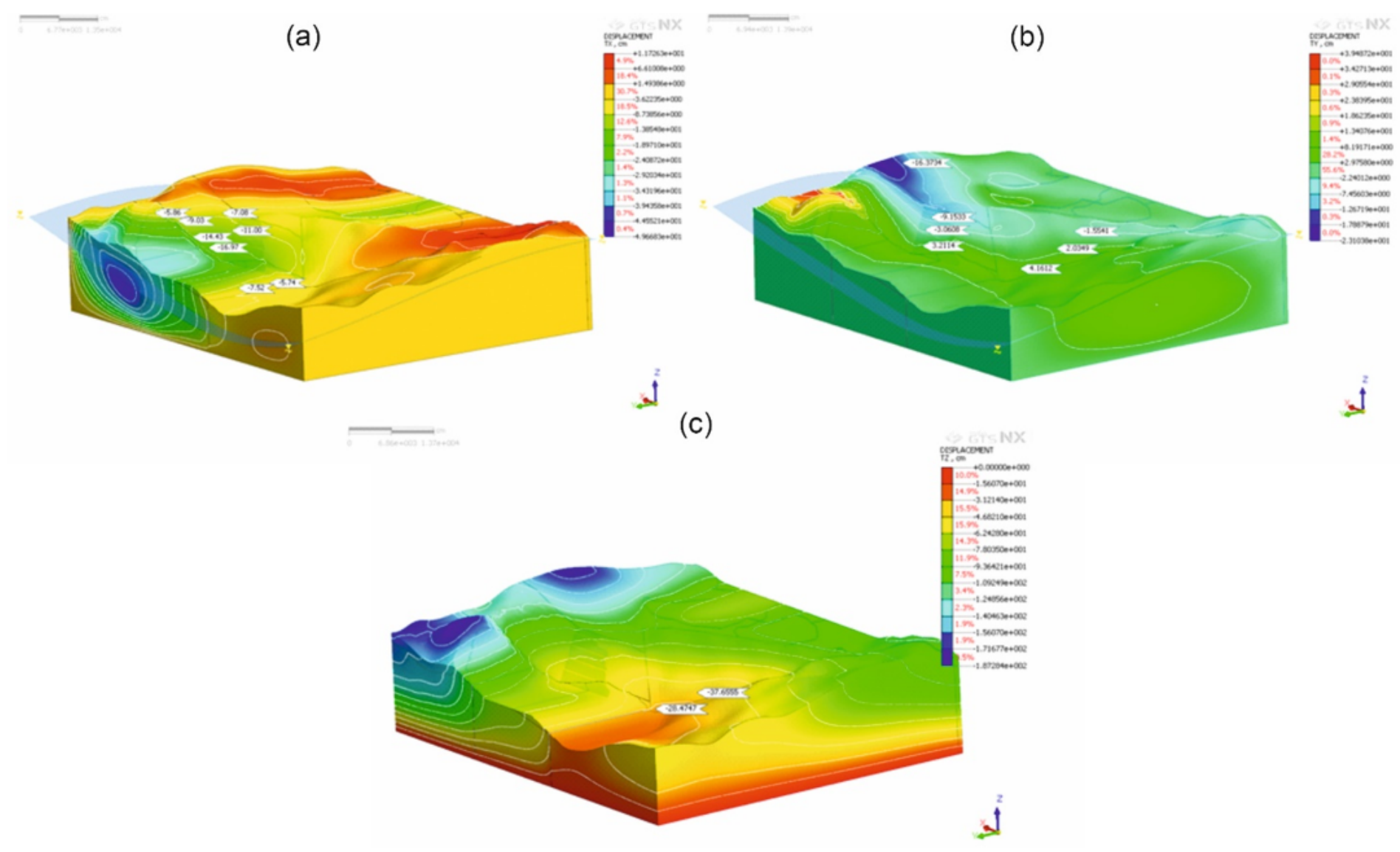

Figure 11

Deformations in (a) x-direction, (b) y-direction, and (c) z-direction after excavation of the slopes 